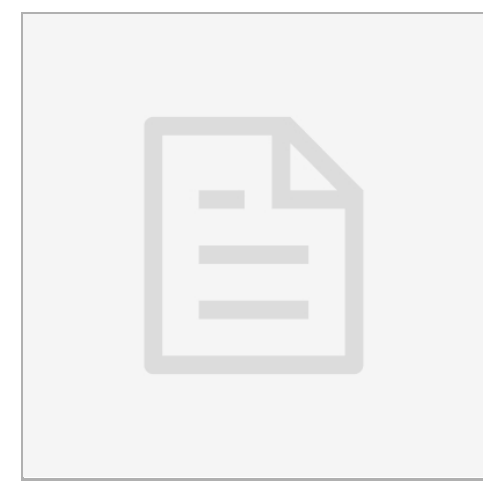

JUN 11, 2019

\section{(3) Prep for FACS on blood samples}

Grace Burgin ${ }^{1}$, Inbal Benhar ${ }^{1}$

${ }^{1}$ Broad Institute

Grace Burgin

\section{ABSTRACT}

To prepare blood samples for flow

\section{open ठaccess}

DOI:

dx.doi.org/10.17504/protocol s.io.32dgqa 6

\section{Protocol Citation: Grace} Burgin, Inbal Benhar 2019. Prep for FACS on blood samples. protocols.io https://dx.doi.org/10.17504/p rotocols.io.32dgqa 6

License: This is an open access protocol distributed under the terms of the Creative Commons Attribution License, which permits unrestricted use, distribution, and reproduction in any medium, provided the original author and source are credited

Protocol status: Working We use this protocol and it's working

Created: Jun 11, 2019

Last Modified: Jun 11, 2019

\section{PROTOCOL integer ID:}

24357

1 Collect blood into EDTA coated tubes 
2 Transfer 50ul into clean tube - include 1 unstained

$\star \star \star$ mix from several mice to have 50 ul for unstained ctrl tube

3 Add $1 \mathrm{ml} \mathrm{ACK}$, incubate at RT for 7 min, centrifuge $5^{\prime} 350 \mathrm{~g}$

4 Resuspend pellet in FACS buffer + antibody mix

5 Incubate in dark for $15^{\prime}$ on ice

6 Wash (centrifuge) in FACS buffer, $5^{\prime} 350 \mathrm{~g}$

7 Resuspend in 300ul FACS Buffer + calcein blue 